\title{
POPULATION DENSITY IN RURAL AREAS AS A DRIVER OF THE HUMAN CAPITAL DEVELOPMENT
}

Jan POLCYN, Stanisław Staszic University of Applied Sciences in Piła, Podchorążych street, no. 10, 64-920 Piła, Poland, jan.polcyn@gmail.com (coreponding author)

Bazyli CZYŻEWSKI, Poznań University of Economics and Business, Al. Niepodległości 10, 61-851 Poznań, Poland, b.czyzewski@ue.poznan.pl

\begin{abstract}
Rural areas are typically characterised by uneven access to education and the resulting varying levels of pupils' educational attainment. The inefficiency of the education system may lead to a decreased level of human capital development in the society. It is therefore vital to identify the factors responsible for the inefficiency of the education system and take steps to mitigate their negative impact.

The aim of the present study is to determine the relationship between the population density in rural areas, the pupils' average level of examination performance and the educational value added.

The analyses were based on the exam results achieved by lower secondary school-leavers in 1,372 rural communes between 2012 and 2014. The original intention was to include all rural communes in the analysis. However, due to the incompleteness of the data concerning some of the communes, they were eventually excluded from the study. The final sample for analysis consisted of about $58 \%$ of all rural communes in Poland.

The communes were divided into classes, based on the criterion of population density. The objects under study were arranged in an ascending order according to the value of the population density variable, and then divided into four classes (class A contained $25 \%$ of communes with the highest population density).

The classes thus defined were used as a qualitative predictor in the subsequently performed ANOVA test. As a next step, contrasts were determined by applying a simple contrast to the analysed classes of communes.

The analyses revealed that the highest examination results were achieved in the communes with the highest population density, while the lowest examination results were found in the communes with the lowest population density. This dependence may be indicative of educational negligence at lower levels of education, in this particular case - at the stage of primary school.

The results of the analyses point to the need for expanding the network of nursery schools. To address the above problem, financial support should be provided from the state budget to social initiatives aimed at increasing the access to nursery schools, e.g. by creating an appropriate system of subsidies for nursery schools run by both local governments and private entities.
\end{abstract}

Keywords: ANOVA, educational effectiveness, human capital, rural areas, educational diversification

\section{INTRODUCTION}

An obligatory education system represents an important aspect of social development. Equal access to education determines the effectiveness of education systems and is an important element in promoting social equality. It is therefore essential for the state to ensure even spatial distribution of education, especially in rural areas. One of the methods for measuring the access of education in a society is to determine the distance to school (Gao et al., 2016). Good quality education allows people to improve their social status and, consequently, to change their social environment, i.e. break out of the patterns of social reproduction. (Bourdieu, 1994). Education has a significant impact on a person's hierarchy of needs, including the structure of expenditure (Turczak, Zwiech, 2013).

Considering the agrarian structure of the Polish countryside (a high degree of fragmentation of agricultural holdings), it is important to give rural inhabitants new opportunities of employment, which can primarily be done by providing them with a level of education similar to that achieved in richer regions of the country, usually characterised by a higher population density.

In the present study, the effects of the education system were measured on the basis of the mean results of the lower secondary school leaving exams and the educational value added per pupil.

The objective of this study was to establish the relationship between the population density in rural areas, the pupils' average level of examination performance and the educational value added.

Copyright (C) 2017 The Authors. Published by Aleksandras Stulginskis University. This is an open-access article distributed under the terms of the Creative Commons Attribution License (CC-BY 4.0), which permits unrestricted use, distribution, and reproduction in any medium, provided the original author and source are credited. 


\section{Factors influencing the effects of the education system}

The studies concerning population density and the families' willingness to transport the children to early school facilities reveal that there is a trend to transport the children at short distances (about $3 \mathrm{~km}$ ). Larger distances to educational facilities result in higher costs of transport for families living in sparsely populated areas. The above-mentioned studies also offer suggestions concerning the need to implement a targeted education policy (Cloney et al., 2016).

From an economic point of view, the basic problem is to maintain an appropriate network of schools whose existence would be justified by the number of pupils attending them. However, due to the deepening demographic crisis, the existing school catchment areas are extended, which means the necessity to transport the children to ever further locations. The studies conducted in the Lubelskie Province showed that the catchment area of a single primary school encompassed 5 villages, whereas a single lower secondary school was attended by pupils from as many as 28 villages. The same studies demonstrated that the distance to school and the related transport difficulties constituted a very serious constraint (Nowak, 2006).

A study carried out in the United States to assess language education at the nursery school level showed that the nursery-school children who lagged behind their peers continued to do so at higher levels of education, especially with respect to mathematics and art subjects (Umansky, 2016). Similar research carried out in Turkey demonstrated a positive relationship between nursery school attendance and the children's attainment at the lower secondary school level with respect to mathematics and the Turkish language exam results (Ivrendi, 2016). By shaping prosocial attitudes and principles of behaviour in children, nursery schools contribute to forming similar attitudes at later stages of education. The above findings were confirmed by the studies conducted in the United States among the children of varied ethnic backgrounds (Broekhuizen et al., 2016).

\section{METHODOLOGY}

The analysis was based on the data concerning lower secondary schools in rural communes. A commune was classified as rural based on the description of communes provided by the Local Data Bank of the Central Statistical Office. Other data concerning the communes, such as population density, level of registered unemployment and the number of children in nursery schools per one place, was also obtained from the Local Data Bank of the Central Statistical Office. The data regarding exam results and educational value added for the period 2012-2014 was obtained from the Ministry of National Education (project: educational value added). The initial plan was to analyse all rural communes (2,372 communes), but due to the incompleteness of the examined data, certain analytical objects were excluded from the study. Eventually, the analysis covered 1,372 communes (about $58 \%$ of all rural communes).

The term "educational value added" used in this study means an increment of pupils' knowledge as a result of a particular educational process. It is therefore a measure of the pupils' progress over a specific research period (Dolata, 2007).

Due to economic reasons, the density of a school network is determined by the density of population. Hence, the latter value was adopted in this study as an indicator showing the distance to school.

The analysed communes were arranged in an ascending order according to the criterion of population density and subsequently divided into 4 quartiles. The first quartile (class A) was composed of $25 \%$ of communes with the highest population density, class D comprised $25 \%$ of communes with the lowest population density.

The authors tested the hypothesis according to which the character of a commune defined through its population density is the qualitative predictor determining the quality (effectiveness) of education. Multivariate significance tests were used, such as Pillai's Trace, Wilks' Lambda, Hotelling's Trace, and Roy's Root, in order to adopt/reject the null hypothesis assuming the equality of vectors of mean population density in favour of an alternative hypothesis according to which the vectors differed significantly (which would confirm the research hypothesis) (Table 2).

Subsequently, a univariate ANOVA test was performed, using population density in a commune as the predictor variable, and examination results and the educational value added per pupil as the dependent variables. Based on the results of the ANOVA test, contrasts between the analysed classes of population density were determined. A post hoc analysis using a simple contrast was carried out in order to assess the degree to which contrast coefficients enable the prediction of group means. In this way, it was possible to assess the proportion of variation (the total variation of mean values of a given variable in all classes) that can be attributed to a given contrast. The sum of squares (SS), or the variation attributed to a contrast, was calculated using formula 1 and divided by SS for a given dependent variable in all predictor classes (Stanisz, 2007).

$$
S S_{L}=\frac{\bar{L}^{2}}{\frac{1}{n} \sum_{i=1}^{k} c_{i}^{2}}
$$

where:
$\bar{L}$ - value of contrast
- number of replications (measurements in a group)
$\mathrm{c}_{\mathrm{i}}-$ weights describing the contrast
Value of contrasts was calculated using formula 2: 


$$
\bar{L}=\sum_{i=1}^{k} c_{i} \bar{x}_{i}, \text { where } \bar{x}_{i} \ldots \bar{x}_{k}, \text { are the means of samples }
$$

\section{RESULTS OF ANALYSES AND DISCUSSION}

The analyses revealed considerable differences in population density between class A (59.36) with the highest population density and class D (27.07) with the lowest population density. The difference was 32.29 (Table 1). Population density probably reflects the ease of access to the network of schools and cultural goods that shape the level of human capital. The above premise has been confirmed by the mean exam scores achieved by lower secondary school leavers in the field of humanities, maths and natural science. The exam results in the field of humanities were the highest in class A (99.24) and the lowest in class D (96.11). This dependence was also confirmed by the scores achieved in mathematics and natural science exams, and by the separately analysed exam scores for the Polish language, history, citizenship education and natural science.

Table 1. Mean values of variables used for the analyses

\begin{tabular}{|c|c|c|c|c|}
\hline \multirow{2}{*}{ Class } & \multirow{2}{*}{$\mathrm{N}$} & \multicolumn{3}{|c|}{ Designation of variable* } \\
\hline & & $\mathrm{X}_{1}$ & $\mathrm{x}_{2}$ & $\mathrm{X}_{3}$ \\
\hline A & 343 & $\uparrow 99.23673$ & $\uparrow 99,19447$ & $\uparrow 99,40623$ \\
\hline $\mathrm{B}$ & 343 & 97.48655 & 97.63408 & 97.71289 \\
\hline $\mathrm{C}$ & 343 & 96.78194 & 97.00390 & 96.75588 \\
\hline $\mathrm{D}$ & 343 & $\downarrow 96.20782$ & $\downarrow 96.71880$ & $\downarrow 96.35213$ \\
\hline Total & 1372 & 97.42560 & 97.63581 & 97.55416 \\
\hline & & $\mathrm{X} 4$ & $\mathrm{X} 5$ & $\mathrm{X} 6$ \\
\hline $\mathrm{A}$ & 343 & $\uparrow 99.20842$ & $\uparrow 99.27664$ & $\uparrow 99.33426$ \\
\hline $\mathrm{B}$ & 343 & 97.73717 & 97.64025 & 97.75418 \\
\hline $\mathrm{C}$ & 343 & 97.17482 & 97.23884 & 97.03237 \\
\hline $\mathrm{D}$ & 343 & $\downarrow 96.89798$ & $\downarrow 96.52164$ & $\downarrow 96.79823$ \\
\hline Total & 1372 & 97.75273 & 97.66684 & 97.72773 \\
\hline & & $\mathrm{X}_{7}$ & $\mathrm{X}_{8}$ & $\mathrm{X}_{9}$ \\
\hline $\mathrm{A}$ & 343 & $\downarrow 0.268322$ & $\downarrow 0.122944$ & $\downarrow 0.145378$ \\
\hline $\mathrm{B}$ & 343 & 0.328753 & 0.149896 & 0.178857 \\
\hline $\mathrm{C}$ & 343 & 0.398001 & 0.181570 & 0.216431 \\
\hline $\mathrm{D}$ & 343 & $\uparrow 0.486808$ & $\uparrow 0.221519$ & $\uparrow 0.265289$ \\
\hline Total & 1372 & 0.370725 & 0.169097 & 0.201628 \\
\hline & & $\mathrm{X} 10$ & $\mathrm{X} 11$ & $\mathrm{X} 12$ \\
\hline $\mathrm{A}$ & 343 & $\uparrow 159.3615$ & $\downarrow 1.903207$ & $\downarrow 7.73878$ \\
\hline $\mathrm{B}$ & 343 & 63.3644 & 2.134082 & 8.59883 \\
\hline $\mathrm{C}$ & 343 & 44.1283 & 2.262682 & 9.43499 \\
\hline $\mathrm{D}$ & 343 & $\downarrow 27.0665$ & $\uparrow 2.403873$ & $\uparrow 10.05578$ \\
\hline Total & 1372 & 73.3789 & 2.176458 & 8.95949 \\
\hline
\end{tabular}

* $x_{1}$ - mean humanities exam score, $x_{2}$-mean mathematics and natural science exam score, $x_{3^{-}}$mean Polish language exam score, $x_{4}$ - mean mathematics exam score, $x_{5^{-}}$mean history and citizenship education exam score, $x_{6}$ - mean natural science exam score, $x_{7^{-}}$aggregate educational value added per pupil, $x_{8}$-educational value added in humanities per pupil, $x_{9}$ - educational value added in mathematics and natural sciences per pupil, $x_{10}$-population per $1 \mathrm{~km}^{2}, x_{11}$-children in nursery schools per 1 place, $x_{12}$-registered unemployment,

$\uparrow$ - maximum value, $\downarrow$ - minimum value

Source: own work based on the analysed data

Judging from the dependencies shown above, similar relationships should be expected with respect to educational value added. Surprisingly though, an opposite dependency could be observed here. The highest educational value added was found in class D for aggregate educational value added per pupil and educational value added in humanities, mathematics and natural science.

Since the educational value added reflects the progress of pupils' knowledge in relation to the previous stage of education (in this case - primary school), it can be assumed that class D with the lowest examination scores and the highest educational value added per pupil was characterised by considerably lower examination results at the stage of primary education. This implies that the areas with lower population density have bigger problems with access to education, which translates into lower educational attainment. Older youth covered by lower secondary school system can partly overcome the barriers to accessing education and achieve relatively higher exam results that expected. However, the results are still lower that those achieved by young people from class A communes.

At the same time, it was found that class D of communes with the lowest population density had an easier access to nursery schools. Relevant literature suggests that nursery school education has a considerable impact on the results achieved in later stages of education. In the case under consideration, however, major difficulty lay in the territorial accessibility of nursery schools, which was caused by the distance to nursery school facilities.

Additionally, the level of registered unemployment in class D was found to be considerably higher than in class A - the difference exceeded $2 \%$ (Table 1). 
Multivariate significance tests led to the rejection of the null hypothesis that assumed the equality of mean examination score vectors in the communes classified according to their population density in favour of an alternative hypothesis which points to significant differences in the mean exam scores in the analysed classes of communes (Table 2 ).

Table 2 Multivariate significance tests

\begin{tabular}{c|c|r|r|r|r|r}
\hline & Test & Value & F & Effect df & \multicolumn{1}{c|}{ Error df } & \multicolumn{1}{c}{$p$} \\
\hline \multirow{4}{*}{$\begin{array}{c}\text { Population density } \\
\text { classes }\end{array}$} & Wilks' Lambda & $\mathbf{0 . 4 6 5 9 3 1}$ & $\mathbf{2 8 . 1 6 8 8 1}$ & $\mathbf{4 2}$ & $\mathbf{4 0 2 9 . 2 4 4}$ & $\mathbf{0 . 0 0}$ \\
\cline { 2 - 7 } & Pillai's Trace & $\mathbf{0 . 5 6 8 3 1 5}$ & $\mathbf{2 2 . 7 0 3 4 8}$ & $\mathbf{4 2}$ & $\mathbf{4 0 8 0 . 0 0 0}$ & $\mathbf{0 . 0 0}$ \\
\cline { 2 - 7 } & $\begin{array}{c}\text { Hotelling's } \\
\text { Trace }\end{array}$ & $\mathbf{1 . 0 7 3 5 2 0}$ & $\mathbf{3 4 . 6 7 6 3 9}$ & $\mathbf{4 2}$ & $\mathbf{4 0 7 0 . 0 0 0}$ & $\mathbf{0 . 0 0}$ \\
\cline { 2 - 7 } & Roy's Root & $\mathbf{1 . 0 0 2 5 4 2}$ & $\mathbf{9 7 . 3 8 9 7 6}$ & $\mathbf{1 4}$ & $\mathbf{1 3 6 0 . 0 0 0}$ & $\mathbf{0 . 0 0}$ \\
\hline
\end{tabular}

Source: own work using the Statistica software v. 12

Table 3. Univariate results for dependent variables

\begin{tabular}{|c|c|c|c|c|c|}
\hline & \multirow{2}{*}{$\begin{array}{l}\text { Degrees of } \\
\text { freedom }\end{array}$} & \multicolumn{2}{|c|}{$\begin{array}{l}\text { Aggregate educational value added per } \\
\text { pupil }\end{array}$} & \multicolumn{2}{|c|}{$\begin{array}{l}\text { Educational value added in humanities per } \\
\text { pupil }\end{array}$} \\
\hline & & SS & MS & SS & MS \\
\hline Intercept & 1 & 4945997 & 4945997 & 1027746 & 1027746 \\
\hline Population density classes & 3 & 1551 & 517 & 492 & 164 \\
\hline Error & 1369 & 43105 & 31 & 12628 & 9 \\
\hline \multirow[t]{3}{*}{ Total } & 1372 & 44656 & & 13120 & \\
\hline & \multirow{2}{*}{$\begin{array}{l}\text { Degrees of } \\
\text { freedom }\end{array}$} & \multicolumn{2}{|c|}{$\begin{array}{l}\text { Educational value added per pupil in } \\
\text { mathematics and natural science }\end{array}$} & & \\
\hline & & SS & MS & & \\
\hline Intercept & 1 & 1464540 & 1464540 & & \\
\hline Population density classes & 3 & 296 & 99 & & \\
\hline Error & 1369 & 14544 & 11 & & \\
\hline Total & 1372 & 14840 & & & \\
\hline
\end{tabular}

Source: own work based on the analysed data

The change in population density in rural communes is an important factor affecting mean examination scores and educational value added per pupil. From a statistical point of view, a significant difference occurs between class A (communes with the highest population density) and class D (communes with the lowest population density). An analysis of contrasts for aggregate educational value added per pupil shows that a change in a commune's class based on population density accounts for over $93 \%$ of the increase in the analysed value (Table 4). Similar dependencies were found by analysing the mean exam scores in humanities (Table 5), and in mathematics and natural science (Table 6).

Table 4 Evaluation of contrasts for the variable: aggregate educational value added per pupil

\begin{tabular}{|c|c|c|c|c|c|c|}
\hline & \multicolumn{6}{|c|}{ Aggregate educational value added per pupil } \\
\hline & Evaluation & $\begin{array}{l}\text { Standard } \\
\text { deviation }\end{array}$ & $\mathrm{t}$ & $\mathrm{p}$ & $\begin{array}{l}\text { Confidence } \\
\text { limit } \\
-95.00 \%\end{array}$ & $\begin{array}{c}\text { Confidence } \\
\text { limit } \\
+95.00 \%\end{array}$ \\
\hline $\begin{array}{l}\text { CONTRAST } 1 \\
\text { (A vs. D, i.e. } 1 ; 0 ; 0 ;-1)\end{array}$ & 2.750 & 0.427 & 6.437 & 0.000 & 1.912 & 3.588 \\
\hline$* \mathbf{S S}_{\text {contrast }} / \mathbf{S S}_{\text {effect }}$ & \multicolumn{6}{|c|}{$3.34(93.30 \%)$} \\
\hline $\begin{array}{l}\text { CONTRAST } 2 \\
\text { (B vs. I, i.e. } 0 ; 1 ; 0 ;-1)\end{array}$ & 0.507 & 0.427 & 1.187 & 0.235 & -0.331 & 1.345 \\
\hline${ }^{*} \mathbf{S S}_{\text {contrast }} / \mathbf{S S}_{\text {effect }}$ & \multicolumn{6}{|c|}{$0.11(3.07 \%)$} \\
\hline $\begin{array}{c}\text { CONTRAST } 3 \\
(\mathrm{C} \text { vs. I, i.e. } 0 ; 0 ; 1 ;-1)\end{array}$ & 0.532 & 0.427 & 1.245 & 0.214 & -0.306 & 1.370 \\
\hline$* \mathbf{S S}_{\text {contrast }} / \mathbf{S S}_{\text {effect }}$ & \multicolumn{6}{|c|}{$0.13(3.63 \%)$} \\
\hline
\end{tabular}

Source: own work based on the analysed data

Table 5 Evaluation of contrasts for the variable: educational value added in humanities per pupil

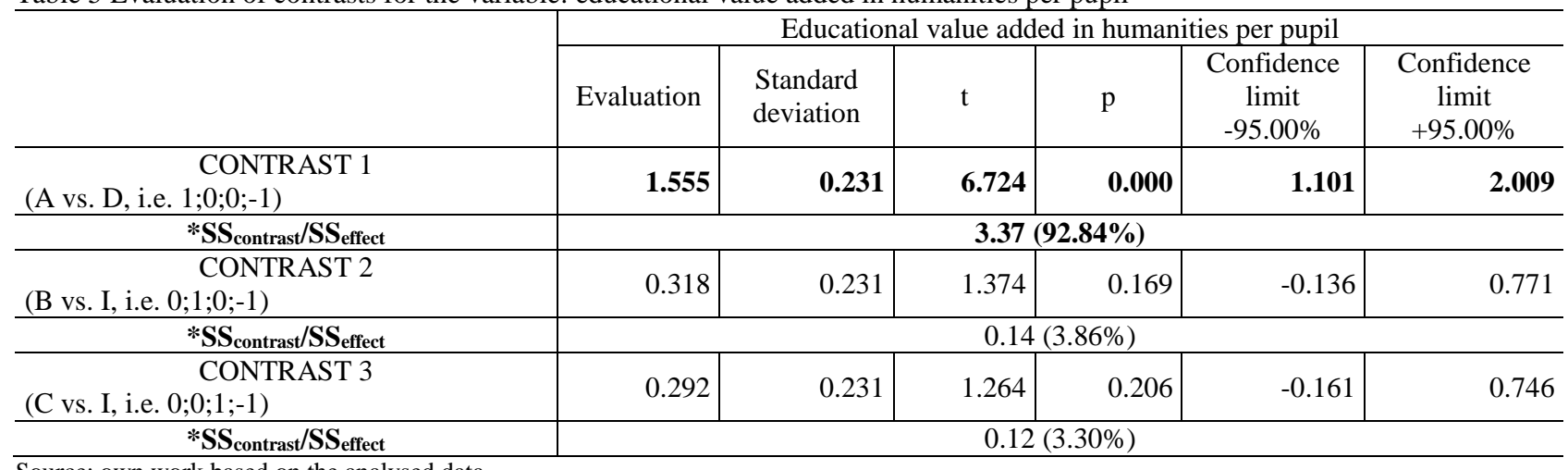


Table 6 Evaluation of contrasts for the variable: educational value added in mathematics and natural science per pupil

\begin{tabular}{|c|c|c|c|c|c|c|}
\hline & \multicolumn{6}{|c|}{ Educational value added in mathematics and natural science per pupil } \\
\hline & Evaluation & $\begin{array}{l}\text { Standard } \\
\text { deviation }\end{array}$ & $\mathrm{t}$ & $\mathrm{p}$ & $\begin{array}{c}\text { Confidence } \\
\text { limit } \\
-95.00 \%\end{array}$ & $\begin{array}{c}\text { Confidence } \\
\text { limit } \\
+95.00 \%\end{array}$ \\
\hline $\begin{array}{l}\text { CONTRAST } 1 \\
\text { (A vs. D, i.e. } 1 ; 0 ; 0 ;-1)\end{array}$ & 1.195 & 0.248 & 4.816 & $\mathbf{0 . 0 0 0}$ & 0.708 & 1.682 \\
\hline$* \mathbf{S S}_{\text {contrast }} / \mathbf{S S}_{\text {effect }}$ & \multicolumn{6}{|c|}{$3.31(94.03 \%)$} \\
\hline $\begin{array}{l}\text { CONTRAST } 2 \\
\text { (B vs. I, i.e. } 0 ; 1 ; 0 ;-1)\end{array}$ & 0.189 & 0.248 & 0.764 & 0.445 & -0.297 & 0.676 \\
\hline$* \mathbf{S S}_{\text {contrast }} / \mathbf{S S}_{\text {effect }}$ & \multicolumn{6}{|c|}{$0.08(2.27 \%)$} \\
\hline $\begin{array}{l}\text { CONTRAST } 3 \\
(\mathrm{C} \text { vs. I, i.e. } 0 ; 0 ; 1 ;-1)\end{array}$ & 0.239 & 0.248 & 0.965 & 0.335 & -0.247 & 0.726 \\
\hline$*$ SS contrast/SS effect $_{\text {. }}$ & \multicolumn{6}{|c|}{$0.13(3.69 \%)$} \\
\hline
\end{tabular}

Source: own work based on the analysed data

\section{SUMMARY}

The analyses conducted above show that educational value added is a good measure reflecting the relative effectiveness of education, i.e. the results of educational processes in relation to previous stages. A higher effectiveness as measured by educational value added was observed in those cases where a greater difference in learning outcomes occurred between the lower and the higher stage of education (in this study, the lower stage of education was represented by primary school). A favourable score of educational value added in sparsely populated areas may be a sign that lower secondary school pupils from those areas show growing motivation to acquire knowledge. Another beneficial factor may be the change of the learning environment as pupils move from primary to lower secondary school.

The dependencies described above, despite reflecting the important role of schools in shaping the pupils' educational attainment, by no means suggest that sparsely populated rural areas have a higher level of education. Such a dependency could only be ascertained by analysing the absolute learning outcomes. In the light of the foregoing, an analysis of the absolute learning outcomes at the primary and lower secondary school level could lead to entirely different conclusions. The analyses conducted above demonstrate only that lower secondary schools in sparsely populated areas are, under current circumstances, characterised by a higher level of learning outcomes as measured by educational value added.

The inequalities resulting from the different standards of living in urban and rural areas should indisputably be mitigated by applying appropriately selected measures. Thus, a well-designed social policy should minimise the inequalities arising from the fact that people do not have the same starting point in the race for a better financial situation, higher social status and the related improved conditions of living. The best way to reduce the gap is to provide all social groups with access to modern education that is adjusted to the needs of knowledge-based economy. It is necessary to ensure that particular individuals have access to proper infrastructure, to the latest technological developments and the entire spectrum of achievements of modern civilization. One of the priorities for national policy should be to provide equal opportunities, abolish barriers, stimulate innovation and promote fair competition. The discrepancies between urban and rural areas can be decreased by supporting the well-designed investment in human capital and infrastructure improvement (Turczak, Zwiech, 2014).

In the light of the presented research findings, it seems extremely important to adopt a socially innovative approach to creating a nursery school network. It is therefore highly appropriate to support social initiatives aimed at increasing the access to nursery school facilities in sparsely populated areas. The system for financing education should allow for financial incentives to support small nursery schools run by private entities or social groups consisting of children's parents in areas with lower population density.

\section{ACKNOWLEDGEMENTS.}

This article is founded by the National Science Centre in Poland (grant no. 2016/21/B/HS4/00653)

\section{REFERENCES}

1. Bourdieu, P. 1994. Reproduction strategies and modes of domination. Actes De La Recherche En Sciences Sociales, Vol. 105, pp. 3-12. https://doi.org/10.3406/arss.1994.3118

2. Broekhuizen, M.L., Mokrova, I.L., Burchinal, M.R., Garrett-Peters, P.T., Key, I. 2016. Classroom quality at pre-kindergarten and kindergarten and children's social skills and behavior problems. Early Childhood Research Quarterly, Vol. 36, pp. $212-222$. https://doi.org/10.1016/j.ecresq.2016.01.005

3. Cloney, D., Cleveland, G., Hattie, J., Tayler, C. 2016. Variations in the Availability and Quality of Early Childhood Education and Care by Socioeconomic Status of Neighborhoods. Early Education and Development, Vol. 27, pp. 384-401. https://doi.org/10.1080/10409289.2015.1076674

4. Dolata, R. 2007. Edukacyjna wartość dodana jako metoda oceny efektywności kształcenia na podstawie wyników egzaminów zewnętrznych, Warszawa, Centralna Komisja Egzaminacyjna. [In Polish]

5. Gao, Y., He, Q.S., Liu, Y.L., Zhang, L.Y., Wang, H.F., Cai, E.X. 2016. Imbalance in Spatial Accessibility to Primary and Secondary Schools in China: Guidance for Education Sustainability. Sustainability, Vol. 8, Iss.16. https://doi.org/10.3390/su8121236 
6. Ivrendi, A. 2016. Investigating kindergarteners' number sense and self-regulation scores in relation to their mathematics and Turkish scores in middle school. Mathematics Education Research Journal, Vol. 28, pp. 405-420. https://doi.org/10.1007/s13394016-0172-4

7. Nowak, A. 2006. Bariery dostępu do edukacji ludności wiejskiej a reforma edukacji. Nierówności spoleczne a wzrost gospodarczy, No. 9, pp. 459-469. [In Polish]

8. Stanisz, A. 2007. Przystępny kurs statystyki z zastosowaniem STATISTICA PL na przykładach z medycyny, Kraków, StatSoft Polska. [In Polish]

9. 9. Turczak, A., Zwiech P. 2013. Czynniki wpływające na strukturę wydatków konsumpcyjnych gospodarstw domowych w Polsce. Studia i Prace Wydziału Nauk Ekonomicznych i Zarzadzania, No. 33, pp. 189-207. [In Polish]

10. 10. Turczak, A., Zwiech, P. 2014. Variability of household disposable income per capita by types of residence in Poland. Statistics In Transition new series, Vol. 15, Iss. 4, pp. 573-590.

11. 11. Umansky, I. M. (2016). To Be or Not to Be EL: An Examination of the Impact of Classifying Students as English Learners. Educational Evaluation and Policy Analysis, 38, Iss. 4, pp. 714-737. https://doi.org/10.3102/0162373716664802 